\title{
Impact of Inorganic Arsenicals on Vegetative Growth of Two Pakistani Origins Sunflower Cultivars
}

\author{
Muhammad Asif Imran, ${ }^{1}$ Feroza Hamid Wattoo, ${ }^{2}$ Muhammad Nawaz Chaudhry, \\ Muhammad Hamid Sarwar Wattoo, ${ }^{3}$ and Khan Rass Masood ${ }^{4}$ \\ ${ }^{1}$ College of Earth and Environmental Sciences, University of the Punjab, Lahore, Pakistan \\ ${ }^{2}$ University Institute of Biochemistry \& Biotechnology, Pir Mehr Ali Shah Arid Agriculture University, Rawalpindi, Pakistan \\ ${ }^{3}$ Eshfaq Ahmad Laboratories Complex, Pakistan Institute of Engineering and Applied Sciences, Islamabad, Pakistan \\ ${ }^{4}$ Department of Botany, University of the Punjab, Lahore, Pakistan
}

Correspondence should be addressed to Feroza Hamid Wattoo; drfhwattoo@uaar.edu.pk

Received 10 November 2014; Accepted 10 May 2015

Academic Editor: Athanasios Katsoyiannis

\begin{abstract}
Copyright (C) 2015 Muhammad Asif Imran et al. This is an open access article distributed under the Creative Commons Attribution License, which permits unrestricted use, distribution, and reproduction in any medium, provided the original work is properly cited.

Inorganic arsenicals impact on vegetative growth of two sunflower (Helianthus annuus L.) cultivars (FH-385 as Hybrid 1 and FH-405 as Hybrid 2) was monitored. Various levels of two different sodium salts of arsenic, namely, sodium arsenate $\left(\mathrm{Na}_{2} \mathrm{HAsO}_{4} \cdot 7 \mathrm{H}_{2} \mathrm{O}\right)$ as source of $\mathrm{As}^{5+}$ and sodium arsenite $\left(\mathrm{NaAsO}_{2}\right)$ as source of $\mathrm{As}^{3+}$, were used to evaluate the effect of arsenic on plant water relation parameters. Significant stress effects were found when arsenic was higher in concentrations ( $>60 \mathrm{mg} / \mathrm{kg}$ soil of both salts) as compared to control plants. Genotype FH-405 showed higher levels for shoot and root length, water contents, number of leaves, and leaf area, which indicates well adaptation of this cultivar in arsenic contaminated environment. T5 (100 mg/kg) of both salts showed notable stressful impacts as compared to low arsenic concentrations $(20,40 \mathrm{mg} / \mathrm{kg})$ and especially control plants in case of all morphophysiological parameters of sunflower cultivars.
\end{abstract}

\section{Introduction}

Worldwide, metal contamination has extremely increased in the biosphere as a result of rapid urban and industrial growth [1]. This situation is alarming in the developing world where untreated waste water is extensively used for irrigation or is disposed of in water resources [2,3]. The Environmental Protection Agency (US, EPA) concluded that arsenic is a Group A carcinogen, known to trigger skin, bladder, and lung cancers, and thus has become a metaphor for poison [4]. A level of $0.1 \mathrm{~g}$ of arsenic trioxide $\left(\mathrm{As}_{2} \mathrm{O}_{3}\right)$ can prove potentially lethal and an ingested dose of 70-80 mg of arsenic trioxide $\left(\mathrm{As}_{2} \mathrm{O}_{3}\right)$ is deadly fatal to humans [5]. Arsenic is ubiquitous, found in air, water, and fuels as well as marine life, and is also present as an impurity in coal and oil-based products such as fuels like petrol, diesel, and motor oil [6, 7]. Globally, the burning of coal has been the major anthropogenic input of arsenic to the surface environment [8].
Arsenic contamination in ground water is a severe global environmental problem [9]. Many arsenic compounds present in the terrestrial and marine environments have been detected [10, 11]. More than 200 minerals containing arsenic have been identified out of which about $60 \%$ are arsenates and $20 \%$ are arsenides, arsenites, and oxides while remaining $20 \%$ are sulphides and sulphosalts [12]. Arsenate $\left[\mathrm{As}^{(\mathrm{V})}\right]$ and arsenite $\left[\mathrm{As}{ }^{(\mathrm{III})}\right]$ are the primary inorganic arsenic forms [13]. There lies a complicated relationship between arsenate and arsenite in soil and water systems by the presence of organic matter, clay minerals, oxides of iron and aluminium, soil redox potential, soil $\mathrm{pH}$, and microbial action [14]. It was reported that arsenate strongly binds iron and manganese oxides and remains in the surface soil layer after deposition [15]. Merwin et al. [16] reported higher arsenic concentration after fifteen years in the top $20-40 \mathrm{~cm}$ of orchard soils treated with lead arsenate. The soil arsenic can be absorbed by the farm crops such as grains, vegetables, and fruits, and 
TABLE 1: Analysis of variance (ANOVA) table for shoot length, root length, shoot: root ratio, and moisture contents in shoot and root of sunflower cultivars under various arsenic levels.

\begin{tabular}{|c|c|c|c|c|c|c|}
\hline \multirow{2}{*}{ Source } & \multirow{2}{*}{$\mathrm{DF}$} & \multicolumn{5}{|c|}{ Mean square } \\
\hline & & Shoot length (cm) & Root length $(\mathrm{cm})$ & Shoot : root ratio & Moisture contents in shoot & Moisture contents in root \\
\hline Varieties (V) & 1 & $593.97^{* *}$ & $22.22^{*}$ & $1.21^{* *}$ & $1525434^{* *}$ & $2374217^{* *}$ \\
\hline Salts (S) & 1 & $1.02^{\mathrm{ns}}$ & $5.56^{\mathrm{ns}}$ & $0.24^{*}$ & $73997^{\mathrm{ns}}$ & $308351^{* *}$ \\
\hline Levels (L) & 5 & $492.52^{* *}$ & $125.30^{* *}$ & $0.03^{\text {ns }}$ & $1322946^{* *}$ & $207840^{* *}$ \\
\hline $\mathrm{V} \times \mathrm{S}$ & 1 & $4.60^{\mathrm{ns}}$ & $14.22^{\mathrm{ns}}$ & $0.69^{* *}$ & $4572^{\text {ns }}$ & $20231^{\mathrm{ns}}$ \\
\hline $\mathrm{V} \times \mathrm{L}$ & 5 & $7.76^{\mathrm{ns}}$ & $2.32^{\mathrm{ns}}$ & $0.13^{*}$ & $397001^{* *}$ & $62792^{*}$ \\
\hline $\mathrm{S} \times \mathrm{L}$ & 5 & $38.49^{* *}$ & $4.98^{\mathrm{ns}}$ & $0.06^{\mathrm{ns}}$ & $186125^{* *}$ & $36827^{\text {ns }}$ \\
\hline $\mathrm{V} \times \mathrm{S} \times \mathrm{L}$ & 5 & $7.08^{\mathrm{ns}}$ & $2.32^{\mathrm{ns}}$ & $0.07^{\mathrm{ns}}$ & $78990^{*}$ & $96389^{* *}$ \\
\hline Error & 48 & 7.31 & 3.90 & 0.04 & 27099 & 23876 \\
\hline
\end{tabular}

${ }^{*}$ Significant $(P<0.05) .{ }^{* *}$ Highly significant $(P<0.01) .{ }^{\mathrm{ns}}$ Nonsignificant $(P>0.05)$.

utilization of these contaminated farm crops as food can have hazardous effects on human and animals health [17].

Arsenic is not essential for plant growth [18]. There are different ways by which plants handle toxic heavy metals such as phytoimmobilization, phytostabilization, rhizofiltration, phytovolatilization, and phytoextraction, the latter being most widely accepted for remediation of soils contaminated with toxic heavy metals [19]. Because of chemical similarities to phosphate, arsenate is able to replace phosphate in many cell reactions and it shows many toxic effects to plants including wilting of new-cycle leaves and retardation of root and top growth [20]. Imran et al. [21] reported that higher levels of inorganic arsenicals have posed a stress over seed germination parameters like germination percentage, seedling vigour index, and length and fresh as well as dry weights of plumules and radicles. Arsenite $\left(\mathrm{As}^{(\mathrm{III})}\right)$ posed more stressful effects than that of arsenate $\left(\mathrm{As}^{(\mathrm{V})}\right)$ contamination [20].

Sunflower (Helianthus annuus L.) of family Asteraceae, tribe Heliantheae, is an annual, erect, broad leaf plant with a strong taproot and prolific later spread of surface roots. It was originated in North America as a "camp follower" of Western Native American tribes who domesticated the crop possibly 1000 BC. It was first introduced to Europe through Spain and spread through Europe as a curiosity until it reached to Russia where it was readily adapted as oilseed crop [22]. In Pakistan, sunflower was introduced in early sixties but its acreage and yield remained stagnant until 1980/81 when its area and yield started to increase in Punjab [23]. Being a short duration crop, it can be fitted well in Pakistan cropping system [24]. It is the most important oilseed crop of the world due to its wide range of adaptability and very high oil contents' seeds, ranging from 40 to $50 \%$ with $23 \%$ protein [25]. Its cultivation is increasing due to high edible oil contents [26]. Imran et al. also reported sunflower as one of the newly added crops to human food chain in Pakistan while researchers, namely [27, 28], considered it as the world's fourth largest oilseed crop.

Most of the research works in context of arsenic accumulation in food crops have been focused on rice (Oryza sativa L.) [20, 29], wheat (Triticum aestivum L.) [30], maize (Zea mays L.) [31], bean plants [32], and so forth. At elevated arsenic concentrations, the reduction in biomass production and oilseed yields was reported in a variety of crops by
Carbonell-Barrachina et al. [32]. With soil application of only $50 \mathrm{mg} \mathrm{As} \mathrm{kg}{ }^{-1}$, the reduction in yield of barley (Hordeum vulgare L.) and rye grass (Lolium perenne L.) [33], wheat (Triticum aestivum L.) [34], rice (Oryza sativa L.) [18], and maize (Zea mays L.) [31] was recorded. There is less extensive work that has been conducted on sunflower (Helianthus annuus L.) [35]. The early vegetative stages (transition stages) are important for R \& D work in which plant is preparing itself to enter in yield producing or reproductive stage and any kind of stress proves to be severely crucial for overall plant growth and yield. The present study was undertaken in context of Pakistani origin genotype varieties to evaluate the effect of various levels of inorganic arsenicals on some important vegetative and plant water relation parameters of sunflower cultivars.

\section{Materials and Methods}

An experiment was conducted in pots on two cultivars of sunflower, namely, FH-385 and FH-415, in the warehouse of the botanical garden, University of the Punjab, Lahore. The seeds were obtained from Ayyub Agriculture Research Institute (AARI), Faisalabad, Pakistan. Ten seeds of each hybrid were sown in each pot and the plants were watered with halfstrength Hoagland's nutrient solution [36] approximately 6 times prior to harvesting and data collection. Clay loam soil having $57 \%$ clay, $29 \%$ sand, $14 \%$ silt, $0.74 \%$ organic matter, $\mathrm{pH}$ (7.8), and $4.7 \%$ nitrogen contents was used for filling the pots according to protocols described by Bouyoucos and Basu [37, 38]. Two arsenic salts, sodium arsenate $\left(\mathrm{Na}_{2} \mathrm{HAsO}_{4} \cdot 7 \mathrm{H}_{2} \mathrm{O}\right)$ and sodium arsenite $\left(\mathrm{NaAsO}_{2}\right)$, were mixed thoroughly in the soil to attain $0,20,40,60,80$, and $100 \mathrm{mg}$ As/ $/ \mathrm{kg}$ soil concentrations. The soil was prepared fifteen days before sowing of seeds. The experiment was laid out in a completely randomized design with three factors comprising two sunflower varieties, two types of arsenic salts, and five levels of each salt. Data regarding morphology, growth, and water relation were recorded before flowering. Plants were uprooted carefully and lengths and fresh weights were calculated readily; after that plants were packed in blotting paper bags and kept in oven for 72 hours at $80^{\circ} \mathrm{C}$ to calculate dry weights. The fresh weight, turgid weight, and dry weights of leaves 


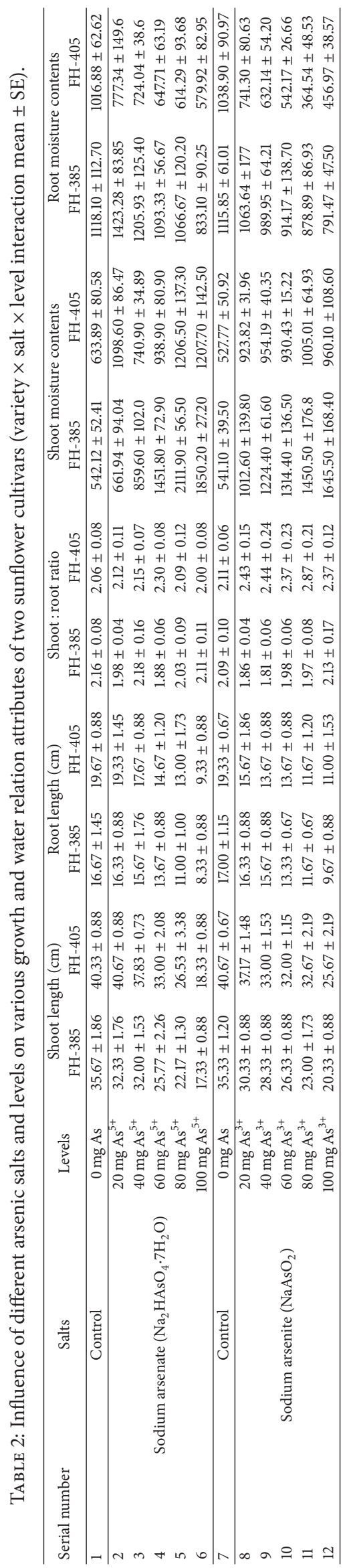


TABLE 3: Analysis of variance (ANOVA) table for number of leaves, leaf succulence, leaf area, and relative water contents of leaf recorded at vegetative stage of sunflower grown under different levels of rhizospheric arsenic.

\begin{tabular}{|c|c|c|c|c|c|}
\hline \multirow{2}{*}{ Source } & \multirow{2}{*}{$\mathrm{DF}$} & \multicolumn{4}{|c|}{ Mean square } \\
\hline & & Number of leaves & Leaf area & Leaf succulence & RWC leaf \\
\hline Varieties (V) & 1 & $0.14^{\mathrm{ns}}$ & $2110.33^{* *}$ & $9.44^{* *}$ & $878.08^{* *}$ \\
\hline Salts (S) & 1 & $0.22^{\mathrm{ns}}$ & $713.79^{* *}$ & $0.91^{\mathrm{ns}}$ & $24.71^{\mathrm{ns}}$ \\
\hline Levels (L) & 5 & $21.96^{* *}$ & $569.25^{* *}$ & $0.59^{\mathrm{ns}}$ & $154.04^{* *}$ \\
\hline $\mathrm{V} \times \mathrm{S}$ & 1 & $1.38^{\mathrm{ns}}$ & $1208.03^{* *}$ & $6.41^{* *}$ & $214.11^{* *}$ \\
\hline $\mathrm{V} \times \mathrm{L}$ & 5 & $0.67^{\mathrm{ns}}$ & $769.14^{* *}$ & $0.15^{\mathrm{ns}}$ & $27.25^{\mathrm{ns}}$ \\
\hline $\mathrm{S} \times \mathrm{L}$ & 5 & $1.29^{\mathrm{ns}}$ & $243.95^{* *}$ & $0.27^{\mathrm{ns}}$ & $133.07^{* *}$ \\
\hline $\mathrm{V} \times \mathrm{S} \times \mathrm{L}$ & 5 & $0.72^{\mathrm{ns}}$ & $372.51^{* *}$ & $0.39^{\mathrm{ns}}$ & $30.56^{\mathrm{ns}}$ \\
\hline Error & 48 & 1.18 & 13.17 & 0.64 & 27.55 \\
\hline
\end{tabular}

${ }^{*}$ Significant $(P<0.05) .{ }^{* *}$ Highly significant $(P<0.01) .{ }^{\text {ns }}$ Nonsignificant $(P>0.05)$. RWC $=$ Relative water contents.

were recorded to calculate succulence and relative water contents in accordance with methods described by Pirzad and Mantovani $[39,40]$ while shoot : root ratio and water contents of shoot and root were registered with Standard Operating Procedures number 2034, U S EPA (1994). Leaf area was measured by computer software (Rosband, W. S. Image J, U. S. National Institute of Health, Bethesda, Maryland, USA, 2008) using images of every 3rd leaf from apical side of stem with the help of digital camera. The data were analyzed statistically using computer software SPSS (version 16) to conclude different interactions and correlations.

\section{Result and Discussion}

The data collected at preanthesis (before flowering) or vegetative stage of both sunflower cultivars (FH-385 as Hybrid 1 and FH-405 as Hybrid 2) was analyzed statistically. It was found that all the different arsenic levels $(0,20,40,60,80$, and $100 \mathrm{mg} / \mathrm{kg}$ in soil) of both inorganic arsenicals sodium arsenate $\left(\mathrm{Na}_{2} \mathrm{HAsO}_{4} \cdot 7 \mathrm{H}_{2} \mathrm{O}\right)$ and sodium arsenite $\left(\mathrm{NaAsO}_{2}\right)$ showed significant effects on about all morphological, physiological, and plant water relation parameters. Two-way analysis of variance (ANOVA) for various growth parameters including shoot and root length $(\mathrm{cm})$ and shoot : root ratio is given in Table 1 . In case of shoot length, significant differences $(P<0.01)$ were found for sunflower varieties and levels of arsenic whereas nonsignificant $(P>0.05)$ differences were recorded in salts. Out of different interactions, salt into level interaction also showed significant differences $(P<0.01)$ but all other interactions among varieties, salts, and levels showed nonsignificant differences. ANOVA for root length also showed that varieties differed significantly $(P<0.05)$ and levels too $(P<0.01)$, whereas salts and all interactions among the three factors showed nonsignificant differences. Varieties and salts also differed significantly in case of shoot to root ratio but levels showed nonsignificant differences whereas out of different interactions variety into salt and variety into levels showed significant differences but variety into salt into level showed nonsignificant differences. Varieties, levels, and all interactions except variety into salt showed significant differences but salts showed nonsignificant differences in case of moisture contents of shoot. Analysis of variance of data regarding moisture contents of root revealed significant differences for varieties, salts, levels, and interaction among varieties, salts, and levels. Decrease in shoot length and root length was obvious with increasing levels or concentrations of arsenic in soil (Table 2). Moisture contents of shoot were increased randomly with increasing level of arsenic in both sunflower varieties while decreasing trend was observed in moisture contents of root especially in $\mathrm{H} 2$ or FH-405.

Shoot length, root length, and number of leaves were all decreased gradually and showed deterrent effects on water contents of shoot and root, with increasing concentrations of arsenic in the rhizosphere, especially the highest concentration of arsenic (100 mg As/kg soil) affected more severely as compared to control (without any As contamination) in case of all growth and plant water relation parameters of both sunflower cultivars (Table 2). Maximum value for shoot length $(40.67 \pm 0.67 \mathrm{~cm})$ was recorded in control (T0) of sunflower variety $\mathrm{H} 2(\mathrm{FH}-405)$ whereas minimum value of shoot length $(17.33 \pm 0.88 \mathrm{~cm})$ in $\mathrm{T} 5(100 \mathrm{mg} \mathrm{As} / \mathrm{kg})$ of $\mathrm{H1}(\mathrm{FH}-$ $385)$, similarly in case of root length highest value (19.67 \pm $0.88 \mathrm{~cm}$ ) was recorded in control plants of FH-405 and minimum root length $(8.33 \pm 0.88 \mathrm{~cm})$ in case of $100 \mathrm{mg}$ As $/ \mathrm{kg}$ soil in FH-385 representing that cultivar FH-405 showed better root growth in arsenic contaminated soil than FH-385. These results are in conformity with those of Liu and Zhang $[7,34]$ who performed experiment on wheat cultivars and applied similar concentrations of arsenic in the soil and recorded reduction in growth parameters of wheat (Triticum aestivum L.) and rape (Brassica napus). Significant variation in number of plant leaves, leaf succulence, relative water contents of leaf, and leaf area in both of sunflower cultivars was observed with increasing the arsenic concentration.

Sunflower varieties, nature of arsenic salts, and all other interactions among the three factors showed nonsignificant differences in case of number of leaves but levels of arsenicals showed significant differences. In case of leaf area sunflower varieties, salts and levels of arsenic, and all interactions among these three factors showed significant $(P<0.01)$ differences (Table 3). Varieties and interactions between varieties and salts showed significant differences for leaf succulence but salts, levels, and interactions of these factors showed nonsignificant differences. In case of relative water contents 


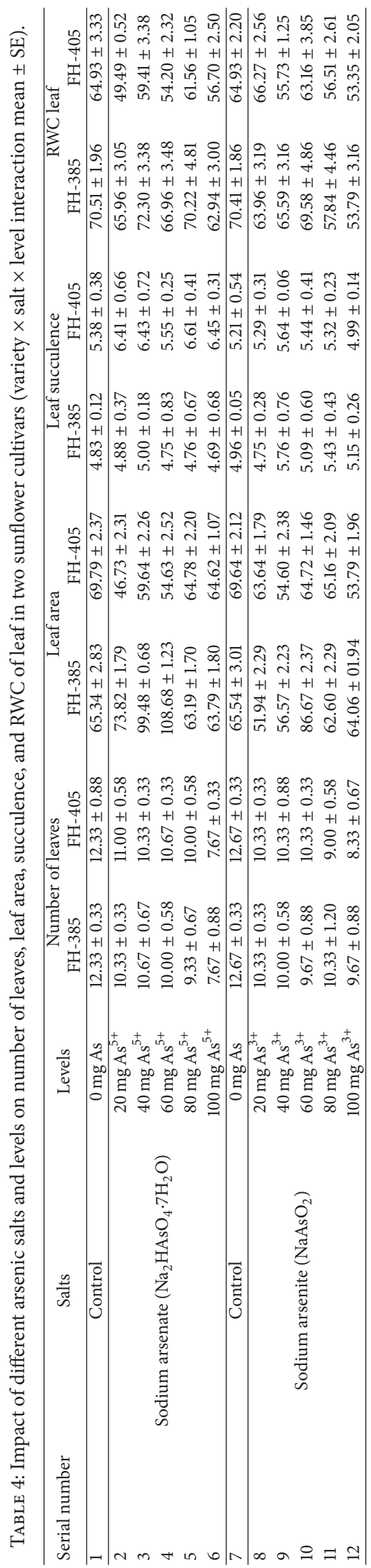


of leaf varieties, levels and interaction of variety into salt and salt into level revealed significant differences but salts and remaining interactions showed nonsignificant differences.

Number of leaves was also reduced with increase in arsenic concentrations in both cultivars and under both arsenicals but leaf area was first increased and then decreased in H1 (FH-385); similarly effect of both arsenicals was random in case of relative water contents of leaves, leaf succulence, and leaf area too in both sunflower varieties (Table 4). Both of the inorganic salts of arsenic behaved similarly showing nonsignificant differences, but different levels of arsenic posed different proportions of stress over both of sunflower cultivars in case of all morphophysiological and water relation parameters recorded during the course of study. Significant differences $(P<0.01)$ for varieties, levels of arsenic, and salts of arsenic used were found in case of leaf area in plants, whereas an unexpectedly maximum value $(108.68 \pm 1.23)$ was found in level $\left(60 \mathrm{mg} \mathrm{As}{ }^{5+} / \mathrm{kg}\right)$ in $\mathrm{H} 1$ (FH-385) plants showing a bit positive effect of arsenic and better growth of sunflower leaves along with its adaptability towards arsenic but when in low concentrations arsenic caused reduction in leaf area because of least value $(46.73 \pm$ 2.31) was recorded in level ( $20 \mathrm{mg} \mathrm{As}{ }^{5+} / \mathrm{kg}$ soil) in $\mathrm{H} 2$ (FH405) cultivar of sunflower showing sensitive behavior in higher concentrations of rhizospheric arsenic.

\section{Conclusion}

It is concluded from the data that both cultivars of sunflower (FH-385 and FH-415) showed similar vegetative growth and physiological development under various levels of arsenic either as sodium arsenate or as sodium arsenite present in soil or in irrigation water. An increase in leaf area was recorded in case of sunflower cultivar FH-385 when arsenic as sodium arsenate was present in soil in low concentrations $(<80 \mathrm{mg}$ As/kg soil) showing ability of this cultivar to cope with arsenic as leaves are major organ controlling plant growth and metabolism. Number of leaves, leaf succulence, and relative water contents of leaf were also moderately affected by all different levels of arsenic either as sodium arsenate or as sodium arsenite; even an increase in leaf succulence compared to control plants was recorded in cultivar $\mathrm{FH}$ 405 under $100 \mathrm{mg}$ As/kg as sodium arsenite, which indicates adaptability of sunflower towards arsenic rich soils having arsenic concentrations up to $100 \mathrm{mg} / \mathrm{kg}$.

\section{Conflict of Interests}

The authors declare that there is no conflict of interests regarding the publication of this paper.

\section{Acknowledgment}

Muhammad Asif Imran is cordially thankful to the Higher Education Commission of Pakistan for their funding to complete research project using various types of instrumentation in different laboratories under 5000 Indigenous fellowship PIN no. 106-1417-BM6-079.

\section{References}

[1] H.-L. Lien and R. T. Wilkin, "High-level arsenite removal from groundwater by zero-valent iron," Chemosphere, vol. 59, no. 3 , pp. 377-386, 2005.

[2] S. R. Kashif, M. Akram, M. Yaseen, and S. Ali, "Studies on heavy metals status and their uptake by vegetables in adjoining areas of Hudiara drain in Lahore," Soil \& Environment, vol. 28, no. 1, pp. 7-12, 2009.

[3] UNIDO, "Industrial policy and the environment in Pakistan," Tech. Rep. NC/PAK/97/018, United Nations Industrial Development Organization (UNIDO), 2002.

[4] B. R. Bondada and L. Q. Ma, Pteridology in the New Millennium, edited by S. Chandra and M. Srivastava, Kluwer Academic, Dodrecht, The Netherlands, 2003.

[5] H. Banejad and E. Olyaie, "Arsenic toxicity in the irrigation water-soil-plant system: a significant environmental problem," The Journal of American Science, vol. 7, no. 1, pp. 125-131, 2011.

[6] X.-Y. Liao, T.-B. Chen, M. Lei, Z.-C. Huang, X.-Y. Xiao, and Z.-Z. An, "Root distributions and elemental accumulations of Chinese brake (Pteris vittata L.) from As-contaminated soils," Plant and Soil, vol. 261, no. 1-2, pp. 109-116, 2004.

[7] Q. J. Liu, C. M. Zheng, C. X. Hu, Q. L. Tan, X. C. Sun, and J. J. Su, "Effect of high concentrations of soil arsenic on the growth of winter wheat (Triticum aestivum L.) and rape (Brassica napus)," Plant, Soil and Environment, vol. 58, no. 1, pp. 22-27, 2012.

[8] F. X. Han, Y. Su, D. L. Monts, M. J. Plodinec, A. Banin, and G. E. Triplett, "Assessment of global industrial-age anthropogenic arsenic contamination," Naturwissenschaften, vol. 90, no. 9, pp. 395-401, 2003.

[9] C. T. Yavuz, J. T. Mayo, C. Suchecki et al., "Pollution magnet: nano-magnetite for arsenic removal from drinking water," Environmental Geochemistry and Health, vol. 32, no. 4, pp. 327334, 2010.

[10] K. A. Francesconi and D. Kuehnelt, "Arsenic compounds in the environment," in Environmental Chemistry of Arsenic, J. W. T. Frankenberger, Ed., pp. 51-94, Marcel Dekker, New York, NY, USA, 2002.

[11] R. Zhao, M. X. Zhao, H. Wang, Y. Taneike, and X. R. Zhang, "Arsenic speciation in moso bamboo shoot-a terrestrial plant that contains organoarsenic species," Science of the Total Environment, vol. 371, no. 1-3, pp. 293-303, 2006.

[12] P. O’Neill, "Mercury," in Heavy Metals in Soils, B. J. Alloway, Ed., pp. 46-53, Blackie Academic \& Professional, London, UK, 2nd edition, 1995.

[13] I. Koch, L. Wang, C. A. Ollson, W. R. Cullen, and K. J. Reimer, "The predominance of inorganic arsenic species in plants from Yellowknife, Northwest Territories, Canada," Environmental Science and Technology, vol. 34, no. 1, pp. 22-26, 2000.

[14] A. Kabata-Pindias and A. B. Mukherjee, Trace Elements from Soil to Human, Springer, Berlin, Germany, 2007.

[15] ATSDR, Toxicological Profile for Arsenic, US Department of Health and Human Services, Agency for Toxic Substances and Disease Registry, Atlanta, Ga, USA, 2007, http://www.atsdr.cdc .gov/toxprofiles/tp2.pdf.

[16] I. Merwin, L. P. T. Pruyne, J. G. Ebel Jr., K. L. Manzell, and D. A. Lisk, "Persistence, phytotoxicity, and management of arsenic, lead and mercury residues in old orchard soils of New York State," Chemosphere, vol. 29, no. 6, pp. 1361-1367, 1994.

[17] W. Zhang, Y. Cai, C. Tu, and L. Q. Ma, "Arsenic speciation and distribution in an arsenic hyperaccumulating plant," The Science of the Total Environment, vol. 300, no. 1-3, pp. 167-177, 2002. 
[18] I. Chaturvedi, "Effect of arsenic concentrations on growth and arsenic uptake and accumulation by rice (Oryza Sativa) Genotype," Electronic Journal of Environmental, Agricultural and Food Chemistry, vol. 5, pp. 1546-1552, 2006.

[19] T. Mahmood, "Phytoextraction of heavy metals-the process and scope for remediation of contaminated soils," Soil \& Environment, vol. 29, no. 2, pp. 91-109, 2010.

[20] M. A. Rahman, H. Hasegawa, K. Ueda, T. Maki, C. Okumura, and M. M. Rahman, "Arsenic accumulation in duckweed (Spirodela polyrhiza L.): a good option for phytoremediation," Chemosphere, vol. 69, no. 3, pp. 493-499, 2007.

[21] M. A. Imran, M. N. Chaudhry, R. M. Khan, Z. Ali, and T. Mahmood, "Toxicity of arsenic (As) on seed germination of sunflower (Helianthus annuus L.)," International Journal of Physical Sciences, vol. 8, no. 17, pp. 840-847, 2013.

[22] D. H. Putnam, E. S. Oplinger, D. R. Hicks et al., Sunflower Field Crop Manual, 1990.

[23] M. M. Aslam and M. R. Akhtar, "Sunflower production technology in a rice-based farming system of the Punjab," Pakistan Journal of Agricultural Social Sciences, vol. 1, no. 1, pp. 29-53, 1986.

[24] M. Akhtar, M. Zubair, M. Saeed, and R. Ahmad, "Effect of planting geometry and water stress on seed yield and quality of spring planted sunflower (Helianthus annuus L.)," Pakistan Journal of Agricultural Sciences, vol. 30, pp. 73-76, 1993.

[25] "Oilseed crops," in Crop Production, M. Hatim and G. Q. Abbasi, Eds., pp. 43-51, National Book Foundation, Islamabad, Pakistan, 1994.

[26] S. Ahmad, Hayat, J. Zeb, and I. Din, "Farmer's uses and decision making criteria regarding fertilizer application and their impact on yield in spring sunflower crop in Mardan District: results of farm level survey, 1986," Sarhad Journal of Agriculture, vol. 4, pp. 763-770, 1988.

[27] J. D. Rodriguez, J. Romero-Garcia, R. Rodriguez-Garcia, and J. L. A. Sanchez, "Characterization of protein from sunflower leaves and seeds. Relationship of biomass and seed yield," in Trends in New Crops and New Uses, J. Janick and A. Whipkey, Eds., pp. 143-149, ASHS Press, Alaxandria, Va, USA, 2002.

[28] J. M. Burke and L. H. Rieseberg, "Fitness effects of transgenic disease resistance in sunflowers," Science, vol. 300, no. 5623, p. 1250, 2003.

[29] P. Bhattacharya, A. C. Samal, J. Majumdar, and S. C. Santra, "Transfer of arsenic from groundwater and paddy soil to rice plant (Oryza sativa L.): a micro level study in West Bengal, India," World Journal of Agricultural Sciences, vol. 5, no. 4, pp. 425-431, 2009.

[30] M. Pigna, V. Cozzolino, A. Violante, and A. A. Meharg, "Influence of phosphate on the arsenic uptake by wheat (Triticum durum L.) irrigated with arsenic solutions at three different concentrations," Water, Air, and Soil Pollution, vol. 197, no. 1-4, pp. 371-380, 2009.

[31] N. Stoeva, M. Berova, and Z. Zlatev, "Physiological response of maize (Zea mays L.) to different levels of As contamination," Biologia Plantarum, vol. 89, pp. 538-543, 2003.

[32] A. A. Carbonell-Barrachina, F. Burló, A. Burgos-Hernández, E. López, and J. Mataix, "The influence of arsenite concentration on arsenic accumulation in tomato and bean plants," Scientia Horticulturae, vol. 71, no. 3-4, pp. 167-176, 1997.

[33] Q. Q. Jiang and B. R. Singh, "Effect of different forms and sources of arsenic on crop yield and arsenic concentration," Water, Air, and Soil Pollution, vol. 74, no. 3-4, pp. 321-343, 1994.
[34] W. D. Zhang, D. S. Liu, J. C. Tian, and F. L. He, “Toxicity and accumulation of arsenic in wheat (Triticum aestivum L.) varieties of China," Phyton, vol. 78, pp. 147-154, 2009.

[35] A. Raab, H. Schat, A. A. Meharg, and J. Feldmann, "Uptake, translocation and transformation of arsenate and arsenite in sunflower (Helianthus annuus): formation of arsenicphytochelatin complexes during exposure to high arsenic concentrations," New Phytologist, vol. 168, no. 3, pp. 551-558, 2005.

[36] D. R. Hoagland and D. I. Arnon, The Water Culture Method for Growing Plant without Soil, vol. 347 of California Agricultural Experiment Station, University of California Berkley Press, Berkley, Calif, USA, 1950.

[37] G. J. Bouyoucos, "Hydrometer method improved for making particle size analyses of soils," Agronomy Journal, vol. 54, no. 5, pp. 464-465, 1962.

[38] P. K. Basu, Methods Manual: Soil Testing in India, Department of Agriculture \& Cooperation, Ministry of Agriculture, New Delhi, India, 2011.

[39] A. Pirzad, M. R. Shakiba, S. Zehtab-Salmasi, S. A. Mohammadi, R. Darvishzadeh, and A. Samadi, "Effect of water stress on leaf relative water content, chlorophyll, proline and soluble carbohydrates in Matricaria chamomilla L.," Journal of Medicinal Plants Research, vol. 5, no. 12, pp. 2483-2488, 2011.

[40] A. Mantovani, A method to improve leaf succulence quantification [M.S. thesis], Federal University of Rio de Janeiro, Rio de Janeiro, Brazil, 1997. 

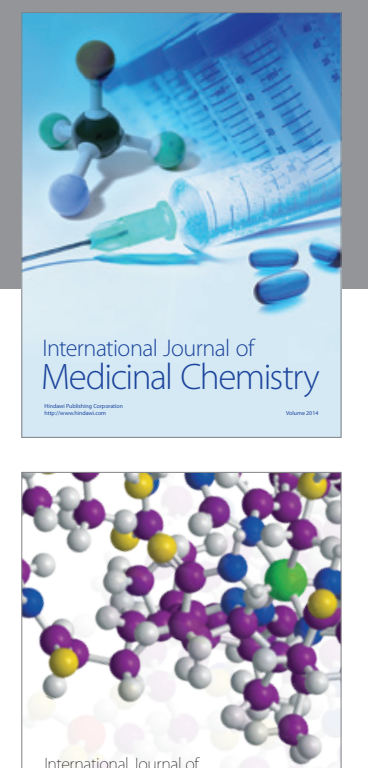

\section{Carbohydrate} Chemistry

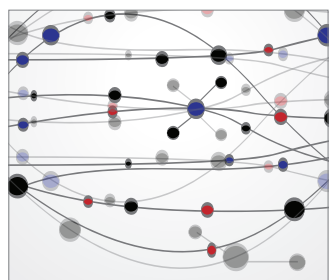

The Scientific World Journal
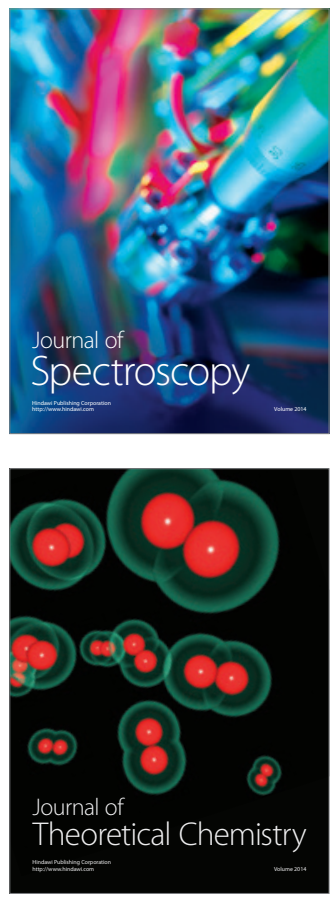
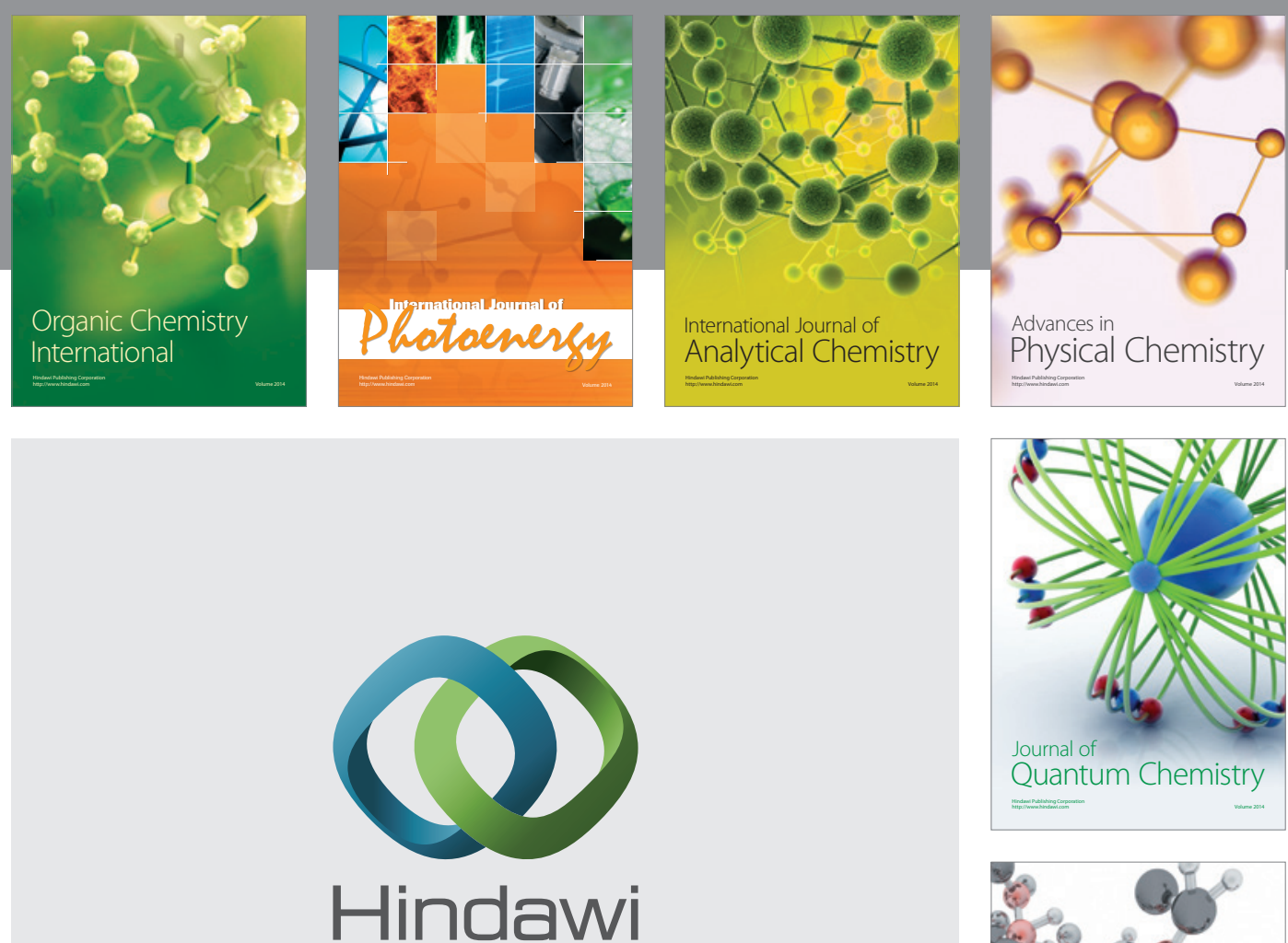

Submit your manuscripts at

http://www.hindawi.com

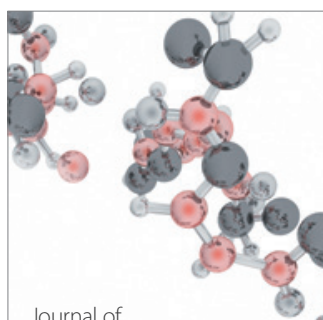

Analytical Methods

in Chemistry

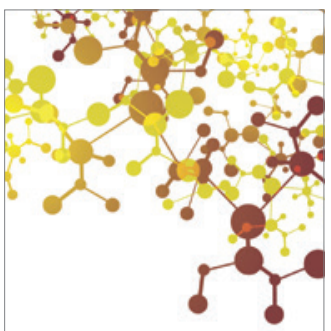

Journal of

Applied Chemistry

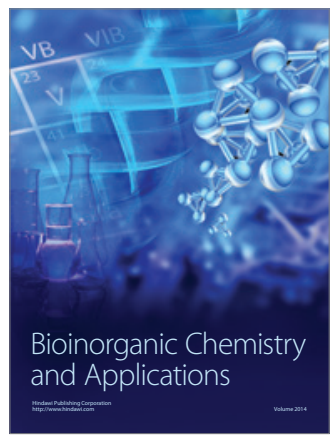

Inorganic Chemistry
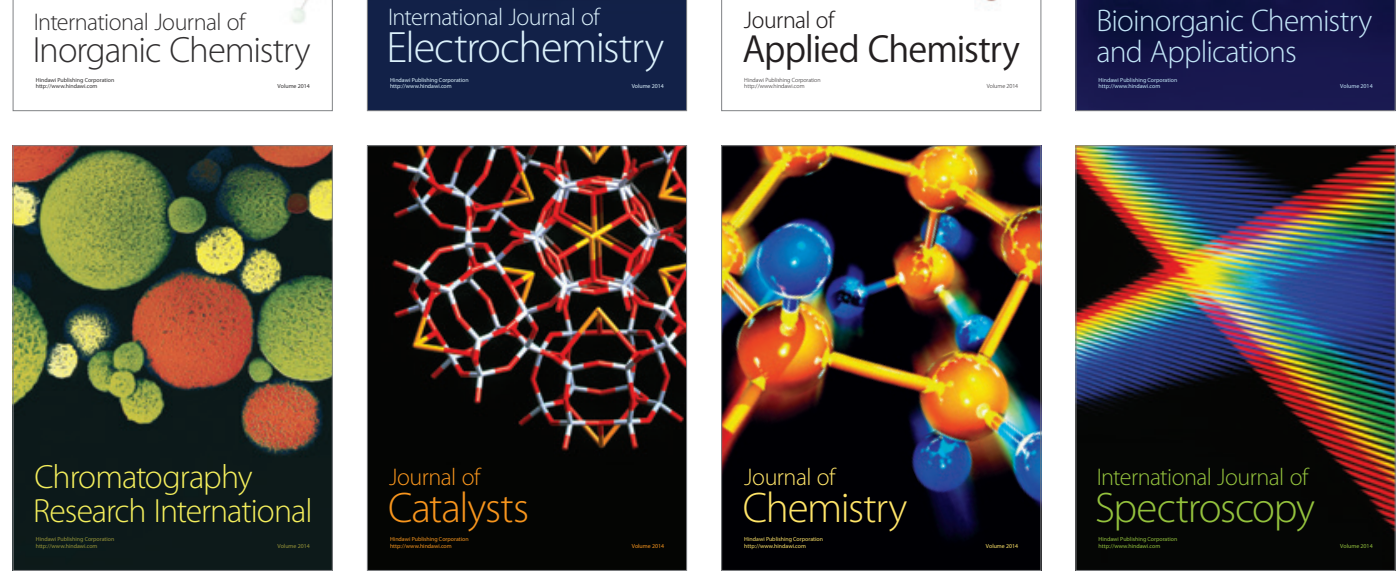